\title{
HUBUNGAN MAKANAN PENDAMPING AIR SUSU IBU (MP-ASI) DENGAN KEJADIAN DIARE PADA ANAK BAYI DI WILAYAH KERJA PUSKESMAS PADUAN RAJAWALI KECAMATAN MERAKSA AJI KABUPATEN TULANG BAWANG
}

\author{
Reni Halimah \\ Program Studi Keperawatan, Sekolah Tinggi Ilmu Kesehatan Mitra Lampung \\ Email: renihalimah.rh@gmail.com
}

\begin{abstract}
Relationship of Complementary Feeding with Occurrence of Infant Diarrhea in Paduan Rajawali Publick Health Center Working Area, Meraksa Aji, Tulang Bawang Districts. Diarrhea is a major cause of morbidity and mortality of childhood in developing countries. There are so many factor that cause of diarrhea, one of them is breasfeeding supplement given too early. The purpose of this research was to determine the relation between of complementary feeding with occurrence of infant diarrhea in Paduan Rajawali Public Health Center working area, Meraksa Aji, Tulang Bawang Distric, on 2016.This research was analytic design with cross sectional approach. Population in this research were all of mother /family who have received an addition food to breast milk and treatment in Paduan Rajawali Public Health Center, Meraksa Aji, Tulang Bawang Districts, had been taken with a technique purposive sampling. Analysis bivariate were used chi square test .The research showed that were significant relation between complementary food with occurrence of infant diarrhea ( $p$-value $=0,030, p$ value $<\alpha=0,05)$.
\end{abstract}

Keywords: Complementary food/ addition food to breast milk, incidence of infant diarrhea

\begin{abstract}
Abstrak: Hubungan Makanan Pendamping Air Susu Ibu (MP-ASI) dengan Kejadian Diare pada Anak Bayi Di Wilayah Kerja Puskesmas Paduan Rajawali Kecamatan Meraksa Aji Kabupaten Tulang Bawang. Diare merupakan salah satu penyebab utama kesakitan dan kematian pada masa anak-anak di negara berkembang. Diare disebabkan oleh berbagai faktor, salah satunya adalah pemberian MP-ASI yang terlalu dini. Tujuan penelitian ini untuk mengetahui hubungan makanan pendamping air susu ibu (MP-ASI) dengan kejadian diare pada anak bayi di Wilayah Kerja Puskesmas Paduan Rajawali Kecamatan Meraksa Aji Kabupaten Tulang Bawang tahun 2016. Jenis penelitian ini adalah penelitian analitik dengan desain cross sectional. Populasi dalam penelitian ini adalah semua ibu/ keluarga anak bayi yang pernah mendapatkan MP-ASI dan berobat di Wilayah Kerja Puskesmas Paduan Rajawali Kecamatan Meraksa Aji Kabupaten Tulang Bawang pada bulan Februari-Maret 2016, yang diambil dengan technic purposive simple. Analisis bivariat menggunakan uji chi square. Hasil penelitian menunjukan bahwa ada hubungan yang signifikan antara makanan pendamping air susu ibu (MP-ASI) dengan kejadian diare pada anak bayi dengan $p$-value $0,030(<\alpha=0,05)$. Peneliti menyarankan kepada petugas kesehatan Puskesmas untuk meningkatkan pelayanan kesehatan dengan cara memberikan penyuluhan kesehatan mengenai waktu, frekuensi, porsi, jenis dan cara pemberian MP-ASI dini.
\end{abstract}

Kata kunci: Makanan pedamping ASI (MP-ASI), Kejadian diare, Bayi

Diare merupakan penyakit yang ditandai dengan buang air besar yang tidak normal dan bentuk tinja yang cair dengan frekuensi yang lebih banyak dari biasanya, bayi dikatakan diare bila sudah lebih dari tiga kali sehari buang air besar, dampak yang ditimbulkan dari penyakit tersebut bukan hanya bagi kesehatan bayi semata, melainkan juga bagi proses tumbuh kembang bayi (Mansjoer, 2009). Masih tingginya angka kesakitan sampai saat ini penyakit diare masih menjadi masalah kesehatan dunia terutama di Negara berkembang. Besarnya masalah tersebut terlihat dari tingginya angka kesakitan dan kematian akibat diare.

Bertambahnya usia bayi mengakibatkan bertambah pula kebutuhan gizinya. Ketika bayi memasuki usia enam bulan ke atas, beberapa elemen nutrisi seperti karbohidrat, protein dan beberapa vitamin serta mineral yang terkandung dalam ASI atau susu formula tidak lagi mencukupi, oleh sebab itu setelah usia enam bulan bayi perlu mulai diberi MP ASI agar kebutuhan gizi bayi atau anak terpenuhi. Dalam pemberian MP ASI, yang perlu diperhatikan 
adalah usia pemberian MP-ASI, frekuensi dalam pemberian MP-ASI, porsi dalam pemberian MPASI, jenis MP-ASI, dan cara pemberian MP-ASI pada tahap awal. Pemberian MP-ASI yang tepat diharapkan tidak hanya dapat memenuhi kebutuhan gizi bayi, namun juga merangsang keterampilan makan dan merangsang rasa percaya diri pada bayi (Kemenkes RI, 2014).

Pemberian makanan pendamping Air Susu Ibu (MP-ASI) yang terlalu dini, MP-ASI kurang dari usia enam bulan, selain belum dibutuhkan juga memungkinkan bayi mendapat infeksi saluran pencernaan lebih besar akibat cara pemberian yang kurang bersih dan belum sempurnanya organ pencernaan bayi baik secara anatomis maupun secara fisiologis. Selain itu makanan dan minuman yang terkontaminasi oleh serangga atau kontaminasi oleh tangan yang kotor, bermain dengan mainan yang terkontaminasi, apalagi pada bayi yang sering memasukkan tangan/apapun ke dalam mulut karena virus ini dapat bertahan hidup di permukaan udara selama beberapa hari (Prawirohardjo, 2010).

Data mengenai kejadian diare dari Dinas Kesehatan Kabupaten Tulang Bawang tahun 2015 diketahui bahwa jumlah penderita diare pada anak yaitu 1582 jiwa yang tersebar di 18 Puskesmas. Berdasarkan laporan profil kesehatan Puskesmas Paduan Rajawali Kabupaten Tulang Bawang, kejadian diare pada anak tahun 2015 di Puskesmas Paduan Rajawali mengalami peningkatan yang cukup signifikan yaitu $31 \%$ dari tahun 2014 yaitu dari 289 kasus menjadi 378 kasus (Profil Kesehatan Puskesmas Paduan Rajawali, 2015). Berdasarkan pra survey yang dilakukan pada tanggal 29 Februari 2016 terhadap 20 bayi di Desa Paduan Rajawali terdapat 15 bayi (75\%) mendapat MP-ASI dini dan 5 bayi (25\%) tidak mendapat MP-ASI dini dari 15 bayi yang mendapat MP-ASI dini 11 bayi (73\%) pernah mengalami penyakit diare dan sisanya 4 bayi $(27 \%)$ tidak mengalami diare. Berdasarkan latar belakang dan fenomena tersebut di atas, maka penulis ingin melakukan penelitian mengenai "Hubungan Makanan Pendamping Air Susu Ibu (MP-ASI) Dengan Kejadian Diare Pada Anak Bayi di Wilayah Kerja Puskesmas Paduan Rajawali Kecamatan Meraksa Aji Kabupaten Tulang Bawang Tahun 2016”.

\section{METODE PENELITIAN}

Desain penelitian yang digunakan dalam penelitian ini adalah desain analitik dengan pendekatan cross sectional. Jenis penelitian ini adalah penelitian kuantitatif. Penelitian ini dilaksanakan di Wilayah Kerja Puskesmas Paduan Rajawali Kecamatan Meraksa Aji Kabupaten Tulang Bawang pada tanggal 27 Juni2 Juli 2016.

\section{HASIL}

\section{A. ANALISIS UNIVARIAT}
Tabel 1. Distribusi Frekuensi Berdasarkan Makanan Pedamping ASI (MP- ASI)dengan Kejadian Diare

\begin{tabular}{lrr}
\hline \multicolumn{1}{c}{ Variabel } & Frekuensi & Persentase \\
\hline MP-ASI & & \\
\hline Diberi MP-ASI & 76 & 45,8 \\
Tidak MP-ASI & 90 & 54,2 \\
\hline \multicolumn{1}{c}{ Jumlah } & 166 & 100,0 \\
\hline Kejadian Diare & & \\
\hline Diare & 82 & 49,4 \\
Tidak diare & 84 & 50,6 \\
\hline \multicolumn{1}{c}{ Jumlah } & 166 & 100,0 \\
\hline
\end{tabular}

Berdasarkan tabel 1 diketahui bahwa dari 166 responden sebagian besar responden tidak diberi MP-ASI yaitu sebanyak 90 responden $(54,2 \%)$ dan sebagian besar responden tidak mengalami diare yaitu banyak 84 responden $(50,6 \%)$.

\section{B. ANALISIS BIVARIAT}

Tabel 2. Hubungan Makanan Pedamping ASI (MP-ASI) denganKejadian Diare

\begin{tabular}{lrrr}
\hline Variabel & \multicolumn{2}{c}{ Kejadian Diare } & \multicolumn{1}{c}{ Total } \\
\cline { 2 - 3 } MP-ASI & Diare & $\begin{array}{c}\text { Tidak } \\
\text { Diare }\end{array}$ & \\
\hline MP-ASI & 45 & 31 & 76 \\
& $(59,2 \%)$ & $(40,8 \%)$ & $(100 \%)$ \\
\hline Tidak & 37 & 53 & 90 \\
MP-ASI & $(41,1 \%)$ & $(58,9 \%)$ & $(100 \%)$ \\
\hline Total & 82 & 84 & 166 \\
& $(49,4 \%)$ & $(50,6 \%)$ & $(100 \%)$ \\
\hline$p$-value $=0,030$, OR CI $95 \%=2,079$ \\
\hline
\end{tabular}

Berdasarkan tabel 2 diketahui bahwa hasil analisis hubungan antara MP-ASI dengan kejadian penyakit diare diperoleh dari 76 responden yang diberi MP-ASI ada 45 responden $(59,2 \%)$ mengalami diare dan 31 responden $(40,8 \%)$ tidak mengalami diare. Sedangkan dari 90 responden yang tidakdiberi MP-ASI ada 37 responden $(41,1 \%)$ mengalami diare dan 53 responden $(58,9 \%)$ tidak mengalami diare. Hasil uji statistik didapatkan $\rho$-value $=0,030 \quad(\rho$ - 
value $<0,05$ ), hal ini berarti terdapat hubungan yang signifikan antara MP-ASI dengan kejadian diare pada anak bayi di Wilayah Kerja Puskesmas Paduan Rajawali Kecamatan Meraksa Aji Kabupaten Tulang Bawang Tahun 2016. Berdasarkan hasil analisis diperoleh nilai $O R=2,079(1,117-3,869)$ berarti bahwa responden yang diberi MP-ASI berisiko mengalami diare sebanyak 2,079 kali dibandingkan dengan responden yang tidak diberi MP-ASI.

\section{PEMBAHASAN}

\section{A. ANALISIS UNIVARIAT}

\section{Makanan Pedamping ASI (MP-ASI)}

Distribusi frekuensi pemberian makanan pendamping air susu ibu (MP-ASI) di Wilayah Kerja Puskesmas Paduan Rajawali Kecamatan Meraksa Aji Kabupaten Tulang Bawang Tahun 2016, responden yang diberi MP-ASIyaitu sebanyak 76 responden (45,8\%), sedangkan responden yang tidak diberi MP-ASI yaitu sebanyak 90 responden $(54,2 \%)$. Berdasarkan hasil penelitian di atas, maka dapat diketahui sebagian besar responden tidak diberi MP-ASI.

Hal ini didukung teori yang menyatakan bahwa MP-ASI adalah makanan atau minuman yang mengandung zat gizi, diberikan kepada bayi atau anak usia 6-24 bulan guna memenuhi kebutuhan gizi selain dari ASI. MP-ASI dianjurkan pada bayi setelah bayi umur 6 bulan sistem pencernaanya sudah relatif sempurna dan siap menerima makanan pendamping ASI. Menjelang usia 6 bulan umumnya bayi menjadi kurang mendapatkan energi dan zat-zat gizi dari ASI semata. Sedangkan bayi harus tumbuh 2 kali atau lebih dari waktu lahir, sehingga pada umur setelah 6 bulan perlu diberikan MP-ASI. Makanan pendamping ASI diberikan agar bayi cukup memperoleh kebutuhan energi, protein dan zat-zat gizi lain untuk tumbuh kembang secara normal (Depkes, 2010).

Hasil penelitian sejalan dengan hasil penelitian Andriana (2010) tentang hubungan pemberian makanan pendamping ASI (MP-ASI) dengan kejadian diare pada bayi usia $<6$ bulan di Desa Koto Tinggi Wilayah Kerja Puskesmas Rambah, terdapat hubungan antara pemberian MP-ASI dengan kejadian diare dengan nilai $p$-value $=0,007$.

Menurut pendapat peneliti hal ini mungkin didukung dengan pendidikan responden rata-rata menengah (SMA/SMK) dimana responden sudah memiliki pemikiran kritis dalam menerima setiap informasi dan pendidikan kesehatan yang diberikan. Responden lebih banyak yang tidak memberikan MP-ASI dini karena mereka sudah memiliki pengetahuan yang baik tentang manfaat ASI untuk bayi usia 0-6 bulan, dan mereka mengetahui dampak atau akibat jika bayi di beri MP-ASI dini atau sebelum usia 6 bulan akan menurunkan konsumsi ASI dan bisa menyebabkan gangguan pencernaan seperti diare.

\section{Kejadian Diare}

Distribusi frekuensi kejadian diare diWilayah Kerja Puskesmas Paduan Rajawali Kecamatan Meraksa Aji Kabupaten Tulang Bawang Tahun 2016, responden yang mengalami diareyaitu sebanyak 82 responden $(59,4 \%)$, sedangkan responden yang tidak mengalami diareyaitu sebanyak 84 responden $(50,6 \%)$. Berdasarkan hasil penelitian di atas, maka dapat diketahui sebagian besar responden tidak mengalami diare.

Menurut WHO (2009) secara klinis diare didefinisikan sebagai bertambahnya defekasi (buang air besar) lebih dari biasanya/lebih dari tiga kali sehari, disertai dengan perubahan konsisten tinja (menjadi cair) dengan atau tanpa darah. Secara klinik dibedakan tiga macam sindroma diare yaitu diare cair akut, disentri, dan diare persisten.

Hasil penelitian sejalan dengan hasil penelitian Aditya Sasongko (2012) tentang hubungan pemberian MP-ASI dengan kejadian diare pada bayi umur 0-6 bulan di Kecamatan Pedan Kabupaten Klaten, didapatkan nilai $p$ value $=0,020$ yang berarti ada hubungan antara pemberian MP-ASI dengan kejadian diare.

Menurut pendapat peneliti kejadian diare ini mungkin disebabkan karena faktor makanan seperti makanan basi, beracun, alergi makanan dan makanan pendamping ASI terlalu dini (sebelum bayi berusia 6 bulan). Pemberian makanan pendamping ASI terlalu dini merupakan salah satu penyebab diare karena sistem pencernaan bayi pada usia 0-6 bulan masih ematur/ belum sempurna jadi belum siap menerima berbagai jenis makanan. Untuk itu sebaiknya makanan pendamping ASI (MP-ASI) sebaiknya diberikan kepada bayi usia lebih dari 6 bulan, hal ini untuk mencegah terjadinya gangguan fungsi pencernaan salah satunya adalah diare.

\section{B. ANALISIS BIVARIAT}

\section{Hubungan Makanan Pedamping ASI (MP- ASI) dengan Kejadian Diare}

Hasil analisis didapatkan $\rho$-value $=0,030$ yang berarti bahwa ada hubungan yang signifikan 
antara makanan pendamping air susu ibu (MPASI) dengan kejadian diare pada anak balita di Wilayah Kerja Puskesmas Paduan Rajawali Kecamatan Meraksa Aji Kabupaten Tulang Bawang Tahun 2016.

Hal ini sejalan dengan teori yang menyatakan bahwa MP-ASI adalah makanan atau minuman yang mengandung zat gizi, diberikan kepada bayi atau anak usia 6-24 bulan guna memenuhi kebutuhan gizi selain dari ASI. Pengenalan dan pemberian MP-ASI harus dilakukan secara bertahap baik bentuk maupun jumlah. Hal ini dimaksudkan untuk menyesuaikan kemampuan alat pencernaan bayi dalam menerima MP-ASI (Depkes RI, 2010). MP-ASI merupakan peralihan asupan yang semata berbasis susu menuju ke makanan yang semi padat. Untuk proses ini juga dibutuhkan ketrampilan motorik oral. Ketrampilan motorik oral berkembang dari refleks menghisap menjadi menelan makanan yang berbentuk bukan cairan dengan memindahkan makanan dari lidah bagian depan ke lidah bagian belakang (Depkes RI, 2010).

Menurut WHO (2009) secara klinis diare didefinisikan sebagai bertambahnya defekasi (buang air besar) lebih dari biasanya/lebih dari tiga kali sehari, disertai dengan perubahan konsisten tinja (menjadi cair) dengan atau tanpa darah. Secara klinik dibedakan tiga macam sindroma diare yaitu diare cair akut, disentri, dan diare persisten. Sedangkan menurut Depkes RI (2012), diare adalah suatu penyakit dengan tandatanda adanya perubahan bentuk dan konsistensi dari tinja, yang melembek sampai mencair dan bertambahnya frekuensi buang air besar biasanya tiga kali atau lebih dalam sehari.

Hasil penelitian ini didukung oleh penelitian Andriana (2010) tentang hubungan pemberian makanan pendamping ASI (MP-ASI) dengan kejadian diare pada bayi usia $<6$ bulan di Desa Koto Tinggi Wilayah Kerja Puskesmas Rambah, terdapat hubungan antara pemberian MP-ASI dengan kejadian diare dengan nilai $p$ value $=0,007$. Penelitian lain juga yang dilakukan oleh Sugeng Maryanto (2013) tentang hubungan pemberian MP-ASI dengan kejadian diare pada bayi umur 0-6 bulan di Desa Bancak Kabupaten Semarang, didapatkan nilai $p$-value $=0,023$ yang berarti ada hubungan antara pemberian MP-ASI dengan kejadian diare. Selanjutnya hasil penelitian Aditya Sasongko (2012) tentang hubungan pemberian MP-ASI dengan kejadian diare pada bayi umur 0-6 bulan di Kecamatan Pedan Kabupaten Klaten, didapatkan nilai $p$ value $=0,020$ yang berarti ada hubungan antara pemberian MP-ASI dengan kejadian diare.
Hasil analisa peneliti untuk responden yang diberi MP-ASI dan tidak mengalami diare, hal ini mungkin disebabkan karena ibu berpendidikan menengah dan tinggi (SMA, SMK, PT), secara umum semakin tinggi tingkat pendidikan seseorang maka semakin banyak pengetahuan dan informasi yang bisa diterima, hal ini akan mempengaruhi perilaku ibu dalam memberikan makanan pendamping ASI (MPASI) pada bayi/balita yaitu dengan cara diberikan pada waktu yang tepat, usia, frekuensi, porsi, cara pemberian dan jenis makanan pendampingnya sesuai dengan ketentuan, seperti MP-ASI diberikan ketika bayi sudah berusia lebih dari 6 bulan dikarenakan sistem pencernaan pada anak usia setelah enam bulan sudah dapat menerima asupan makanan dengan baik, frekuensi pemberian MP-ASI nya sudah baik tidak berlebihan seperti MP-ASI diberikan 3 kali sehari, diberikan dengan porsi yang tepat pada setiap kali makan yaitu dengan jumlah takaran makan sesuai dengan usia anak dan MP-ASI diberikan dengan cara yang baik dan benar seperti mencuci tangan sebelum menyentuh makanan, mencuci bahan makanan dan peralatan makan dengan bersih, menyajikan makanan dengan baik.

Begitu juga berdasarkan analisa peneliti untuk responden yang tidak diberi MP-ASI dan mengalami diare, hal ini mungkin terjadi karena ibu kurang memperhatikan dalam jenis makanan, porsi makanan tidak sesuai atau diberikan secara berlebihan, frekuensi makan lebih dari 3 kali, jenis makanan tidak sesuai dengan usia bayi atau dalam menyajikan makanan kurang terjaga, kebersihan cara penyimpanan yang kurang baik (terbuka) sehingga makanan terkontaminasi oleh bakteri juga merupakan penyebab diare.

Menurut pendapat peneliti bahwa makanan pendamping ASI (MP-ASI) berpengaruh terdahap kejadian diare. Ibu-ibu diWilayah Kerja Puskesmas Paduan Rajawali Kecamatan Meraksa Aji Kabupaten Tulang Bawang, memberikan MP-ASI pada bayinya yang berumur $0-6$ bulan, hal ini terjadi karena ibu menganggap bila bayinya menangis bayi lapar dan perlu memberi tambahan MP-ASI dan ibu menganggap bahwa ASI saja tidak cukup untuk kebutuhannya, ibu juga merasa lebih tenang bila bayinya kenyang dan tidak rewel. Ibu juga tidak tahu akibat pemberian MP-ASI terlalu dini. Padahal ASI saja sudah merupakan makanan yang baik untuk bayi karena komponen zat makanan tersedia dalam bentuk yang ideal dan seimbang untuk dicerna dan diserap secara optimal oleh bayi. ASI saja sudah cukup untuk memenuhi kebutuhan pertumbuhan bayi sampai umur 4-6 bulan . 
Berdasarkan hasil penelitian dapat diambil kesimpulan bahwa MP-ASI tidak berbahaya dan dibutuhkan bagi balita, jika MP-ASI diberikan pada waktu yang tepat, dengan ukuran yang sesuai dan dengan cara yang baik seperti diberikan pada bayi setelah bayi berusia 6 bulan, diberikan dengan porsi sedikit demi sedikit, diberikan dengan cara yang baik dan bersih, maka tidak akan menyebabkan kejadian penyakit yang tidak diinginkan seperti penyakit saluran cerna salah satunya adalah penyakit diare.

\section{SIMPULAN}

Berdasarkan hasil penelitian dan pembahasan, maka dapat disimpulkan sebagai berikut:

a. Sebagian besar anak balita tidak diberi MPASI di Wilayah Kerja Puskesmas Paduan Rajawali Kecamatan Meraksa Aji Kabupaten Tulang Bawang Tahun 2016 yaitu berjumlah 90 responden $(54,2 \%)$.

b. Sebagian besar anak balita tidak menderita diare di Wilayah Kerja Puskesmas Paduan Rajawali Kecamatan Meraksa Aji Kabupaten Tulang Bawang Tahun 2016yaitu berjumlah 84 responden $(50,6 \%)$.

c. Ada hubungan yang signifikan antara makanan pendamping ASI (MP-ASI) dengan Kejadian diare pada anak balita di Wilayah Kerja Puskesmas Paduan Rajawali Kecamatan Meraksa Aji Kabupaten Tulang Bawang Tahun 2016 dengan $p$-value $=0,030$.

\section{SARAN}

1. Bagi petugas kesehatan perlu meningkatkan promosi kesehatan mengenai dampak atau akibat dari pemberian MP-ASI dini kepada bayi yaitu sebelum bayi berusia 6 bulan, yang ditujukan pada ibu hamil dan ibu menyusui sehingga memiliki pengetahuan yang baik mengenai ASI maka pemberian minuman maupun makanan tambahan (MPASI) tidak akan diberikan kepada bayi sebelum bayi berusia lebih dari 6 bulan. Hasil penelitian diharapkan dapat menjadi bahan referensi khususnya yang berhubungan dengan makanan pendamping ASI (MP-ASI) dengan kejadian diare pada anak bayi. Selanjutnya bagi Institusi Keperawatan diharapkan dapat meningkatkan pelayanan kesehatan kepada masyarakat dengan cara bekerjasama dengan Instansi Kesehatan atau tokoh masyarakat terutama tentang dampak dari makanan pendamping ASI (MP-ASI) pada bayi sebelum usia 6 bulan.

2. Bagi peneliti selanjutnya disarankan agar dapat meneliti variabel lainnya yang lebih bervariasi dan mencakup penelitian yang lebih luas dengan metode penelitian yang berbeda yang belum diteliti yang berkaitan dengan penelitian ini seperti faktor-faktor lain yang mempengaruhi kejadian penyakit diare.

3. Bagi ibu-ibu disarankan agar memberikan ASI eklusif sampai 6 bulan kepada bayinya dan perlu memperhatikan pemberian makanan pedamping ASI (MP-ASI) baik waktu pemberian, frekuensi, jenis makanan, porsi dan cara pemberian yang baik dan benar. Selain itu juga diharapkan ibu-ibu untuk selalu aktif mengikuti penyuluhan mengenai MP-ASI dan penyakit diare.

\section{DAFTAR PUSTAKA}

Andriana. 2010. Hubungan Pemberian Makanan Pendamping ASI (MP-ASI) dengan Kejadian Diare Pada Bayi Usia <6 bulan di Desa Koto Tinggi Wilayah Kerja Puskesmas Rambah. Jurnal Keperawatan. http://www.andriana.online.com (Diakses 7 Maret 2016).

Alimul, H. 2008. Riset Keperawatan dan Teknik Penulisan Ilmiah. Jakarta: Salemba Medika.

Arikunto, S. 2010. Prosedur Penelitian, Suatu Pendekatan Praktek. Jakarta: Rineka Cipta.

Departemen Kesehatan Republik Indonesia. 2010. Tentang Pedoman Pemberian Makanan Pedamping Air Susu Ibu (MPASI). Jakarta. http://www. google.co.id/search=firefox=departemen $+\mathrm{k}$ esehatan+republik+indonesia=Penelusuran +Google. (Diakses pada tanggal 3 April 2016).

Dinas Kesehatan Lampung. 2016. Profil Kesehatan Provinsi Lampung. Lampung.

Dinas Kesehatan Kabupaten Tulang Bawang. 2016. Profil Kesehatan Kabupaten Tulang Bawang. Lampung. 
Kementerian Kesehatan RI. 2014. Pedoman Tata Laksana Diare Balita. Jakarta.

Mansjoer.A, dkk. 2009. Kapita Selekta Kedokteran. Edisi ketiga. Jakarta: Media Aesculapius.

Prawirohardjo, S. 2010. Ilmu Kebidanan. Edisi keempat. Jakarta: Bina Pustaka Sarwono.

Puskesmas Paduan Rajawali. 2015. Profil Kesehatan Puskesmas Paduan Rajawali. Kabupaten Tulang Bawang.

Sasongko. 2012. Hubungan Pemberian MP-ASI dengan Kejadian Diare pada Bayi Umur 06 bulan di Kecamatan Pedan Kabupaten
Klaten Surakarta. Jurnal Kesehatan. http://www.sasongko.online.com (Diakses pada tanggal 10 Maret 2016).

Sugeng, M. 2013. Hubungan Pemberian MP-ASI dengan Kejadian Diare pada Bayi Umur 0-6 bulan di Desa Bancak Kabupaten Semarang. Jurnal Kesehatan dalam http://www.sugeng.online.com. (Diakses pada tanggal 10 Maret 2016).

WHO. $2009 . \quad$ Diare. http://wwwblogspot.com/2014/diare.html (Diakses pada tanggal 2 April 2016). 